\title{
Effect of Machined Surface Shape on Sound Reflection
}

Martin Vasina ${ }^{1}$, Ondrej Bilek ${ }^{2}$

${ }^{1}$ Faculty of Mechanical Engineering, VSB-Technical University of Ostrava, Department of Hydromechanics and Hydraulic Equipment. 17. listopadu 15/2172, 70833 Ostrava-Poruba. Czech Republic. E-mail: martin.vasina@vsb.cz

${ }^{2}$ Faculty of Technology, Tomas Bata University in Zlin, Department of Production Engineering. T. G. Masaryka 5555, 76001 Zlin. Czech Republic. E-mail: bilek@ft.utb.cz

Sound reflection of materials is influenced by many factors, e.g. by material type, density, thickness, porosity, angle of sound incidence, surface shape and excitation frequency of acoustic wave. The aim of the paper is to investigate the surface shape effect of expanded polyvinylchloride material on sound reflection. For this reason polyvinylchloride samples of different surface shapes and perforations were produced on universal and $\mathrm{CNC}$ machine tool. The material ability to reflect sound of the investigated polyvinylchloride samples was experimentally measured by means of the transfer function method on Kundt's impedance tube. The material samples were subsequently compared in terms of their sound reflection. It was verified that the highest sound reflection was obtained in case of the smooth surface polyvinylchloride sample.

Keywords: Sound Reflection, CNC Milling, Surface Shape, Excitation Frequency, Polyvinylchloride.

\section{References}

[1] NOVÝ, R. (2000). Hluk a chvěni. 389 p. ČVUT, Praha (in Czech).

[2] BÍLEK, O., VAŠINA, M. CNC Milling and Manufacturing of Grove Shapes for Light Reflection Measurement. In: Manufacturing Technology. 2014, Vol. 14, No. 4, pp. 516-522. Elsevier. Netherlands.

[3] MADL, J., HOLEŠOVSKY, F. (2008). Integrita obrobených povrchi̊ z hlediska funkčnich vlastností. 230 p. UJEP, Usti nad Labem (in Czech).

[4] VASILKO, Karol. New experimental dependence of machining. In: Manufacturing Technology. 2014, Vol. 14, No. 1, pp. 111-116. Elsevier. Netherlands.

[5] LEGUTKO, S., KROLCZYK, G., KROLCZYK, J. Quality evaluation of surface layer in highly accurate manufacturing. In: Manufacturing Technology. 2014, Vol. 14, No. 1, pp. 50-56. Elsevier. Netherlands.

[6] SAEKI, Y., EMURA, T. Technical progresses for PVC production. In: Progress in polymer science. 2002, Vol. 27, No. 10, pp. 2055-2131. Pergamon Elsevier Science Ltd. England.

[7] ENDO, H., ETSUO, M. Small-hole drilling in engineering plastics sheet and its accuracy estimation. In. International Journal of Machine Tools and Manufacture. 2006, Vol. 46, No. 6, pp. 575-579. Elsevier. England.

[8] FETECAU, C., STAN, F., MUNTEANU, A., POPA, V. Machining and surface integrity of polymeric materials. In. International Journal of Material Forming. 2008 Vol. 1, No. 1, pp. 515-518. Springer. France.

[9] ISO 10534-2:1998 Acoustics - Determination of sound absorption coefficient and impedance in impedance tubes - Part 2: Transfer function method.

[10] HAN, F. S., SEIFFERT, G., ZHAO, Y. Y., GIBBS, B. Acoustic absorption behaviour of an open-celled aluminium foam. In. Journal of Physics D-Applied Physics. 2003 Vol. 36, No. 3, pp. 294-302. IOP Publishing Ltd. England. 